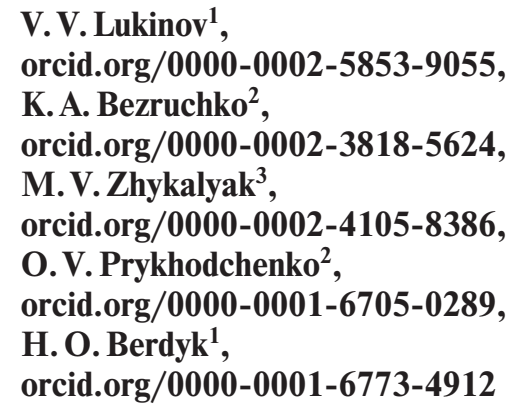

\title{
FORECAST OF METHANE EMISSION FROM THE UNDERMINED COALROCK MASSIF
}

Purpose. To develop an algorithm of forecasting the methane emission from the undermined coalrock massif according to the data of coal production, the values of absolute methane content of a mine and indexes of the methane-bearing capacity of coal beds that are developed.

Methodology. Statistical processing of actual data concerning the methane-bearing capacity of coal beds that are developed as well as the volumes of methane emission and coal production. Based on the obtained stable values of the specific methane emission and the volumes of coal production, the total volumes of methane entry are calculated, and with the exception of methane release from the coal beds, the volumes of methane entry from the coalrock massif are estimated.

Findings. The algorithm of forecasting the quantity evaluation for methane emission from the undermined coalrock massif in operating coal mines is developed. Data analysis 10 years concerning the methane emission while coal beds mining at "PivdennoDonbaska-1" and "Pivdenno-Donbaska-3" mines has been carried out for. An algorithm has been developed for the forecasting factor of methane emission from the undermined coalrock massif, which consists in establishing generalized values of methane emissions into a mine, calculating specific methane emissions from coal, based on the natural and residual methane bearing capacity of coal beds that are developed and a rough estimate for the amount of methane emission from the rock massif containing working coal beds.

Originality. The algorithm for quantitative estimation of methane emission separately from the undermined coalrock massif was developed for the first time, and examples of its practical application by calculation of mining and geological data at "Pivdenno-Donbaska-1" and "Pivdenno-Donbaska-3" mines are presented.

Practical values. The developed algorithm for calculating methane emission from the undermined coalrock massif can be used to forecast the methane emission of operating and closed mines in order to evaluate the possibility of its practical industrial production.

Keywords: coal mines, undermined coalrock massif, methane emission, emission forecast

Introduction. At present one of the main problems of the national economy in Ukraine is energy supply, first of all, by its own hydrocarbon feed. The limited energy resources and their uneven distribution in the world have raised the issue of energy security to the level of the most important tasks facing any state. A number of conditions are necessary for the successful implementation of energy independence, one of which is the availability of a country's own resources and strategic reserves. Ukraine is one of the countries in the world that has reserves of all types of energy resources (oil, natural gas, coal, peat, uranium, and others), but the reserves-to-production ratio, their production and usage are different and in total they do not form the adequate level of energy security. Since today Ukraine largely depends on the import of energy resources, primarily natural gas, the priority for our country is to find new sources of energy supply, including gas from unconventional deposits [1].

The difficult situation with energy carriers in Ukraine requires the involvement of possible additional reserves. In particular, methane reserves in "Pivdenno-Donbaska-3" mine field are 3.5 million cubic meters, and the annual production experience is 3.6 million cubic meters at Lavretiivska dome structure, at the same South-Donbas geological-industrial district of Donbas, it attests to the high potential future concerning the methane accumulations presence in the coalrock massifs at mines of this district, in general, and sand collectors, in particular. Confirmation in the prospects of the coalbed

(C) Lukinov V.V., Bezruchko K.A., Zhykalyak M.V., Prykhodchenko O. V., Berdyk H. O., 2020 methane involvement into the fuel and energy complex, which is located in the mountain group, is the balance of its distribution, presented in paper [2], with reference to the analysis of M. V. Zhykalyak data, where it is indicated that the methane reserves in the rocks of the coal-bearing strata are $82.1 \%$ of the total reserves. Since the search for deposits in traditional geological structures, previously being considered as promising, currently, they are almost completed, prospects of overcoming the shortage of hydrocarbons may be associated with sources of non-conventional type, in particular, coal methane [3]. Ukraine has significant methane resources of coal deposits, which according to the specialists' research are several trillions of cubic meters $[1,4]$. However, at present, the volumes of production and use of this energy source are insignificant; they do not exceed several tens of millions of cubic meters. Whereas in economic terms leading countries in the world (the USA, Germany, the UK, Australia) attract hundreds of millions and even billions of cubic meters of coal gas to the energy sector, including coal bed methane (CBM), coal mine methane (CMM), extraction of which is carried out by methods of current degassing, gas from worked longwalls and closed mines (CAM coal abandoned methane). The practice of carrying out such works abroad confirms the prospects, economic, and environmental efficiency of its production and disposal. Thus, in the United States since 2010, methane production in coal deposits reaches at least 60 billion cubic meters per year, which is more than $10 \%$ of the total dry gas produced [5]. The extraction of coal methane also contributes to the safe conduct of mining operations $[6,7]$ and to the improvement of the ecological state of the environment $[8,9]$ by reducing harmful emissions into 
the atmosphere [10]. Most of the scientific papers concerning the coal methane release are devoted to the evaluation of the overall scope of harmful emissions [11, 12].

The problem-solving in the efficient usage of methane in coal deposits depends on the research on conditions of its distribution in the coal-bearing strata [13]. In order to ensure safe working conditions at the existing gas coal mines, constant monitoring of the gas regime is carried out, including both measuring the qualitative composition of the gas-air mixture and quantitative determination of methane release at specified intervals in individual sections of the mine field. Over the long period of the mine operation, a large real-data file on changes in its gas regime is collected, which, depending on the scope of generalization by time (minutes, days, months, years) or space (longwall, section, horizon, mine), can be used for retrospective analysis of the impact of various mining and geological and mining-engineering factors on the formation of methane emission sources, as well as forecasting evaluations of the quantitative characteristics of methane flow [14].

The specificity of methane coal deposits lies in the fact that the main gas-bearing rocks - coals and sandstones - are practically impermeable, so methane in them is mainly in a weakly bound or immobile state [15]. The stability of the water/gas ratio indicates the presence of the so-called "scattered" gaswater contact. Low permeability values of Donbas sandstones, which are the average hundredth or thousandth of a millidarcy prevent the gas-water redistribution, i.e. the formation of "concentrated" gas-water contact (which one should mean the classical essence of the "gas-water contact" term from the viewpoint of petroleum-gas geology), and as a consequence, gas concentrations in significant volumes in the form of clusters suitable for industrial production.

The formation of gas deposits in coal-bearing strata can occur due to the gas redistribution in the coalrock massif when natural or technogenic factors increase the mobility of methane in the system and promote the activation of its migration [15]. Methane release can occur, for example, due to tectonic processes, when cracking that emergences in the decompression zone increases the permeability of coal-bearing rocks, disturbs the stable balance in the "water-gas" system in the rock massif, supports the formation of zones or individual accumulations of methane, differing from background methane distributions not by volumes, but by increased crack-pore or crack gas permeability.

Processes of migration, accumulation and conservation of methane are closely related to the complex interaction and mutual impact of single phases (water and gas) in the "watergas" system in the rock massif. Model [15] in the existence of the "water-gas" system, based on the mutual impact of its components (water and gas), depending on their quantitative ratio in the rock massif, allows us to understand the mechanism of formation and conservation conditions of gas deposits, as well as theoretically quantify parameters of water and gas saturation of reservoir rocks and rocks that shield gas deposits. The condition for the existence of a gas deposit in sandstones is the presence in the pores of at least $50 \%$ of the gas at the appropriate pressure. At high values of natural humidity, when the degree of moisture pores filling (water saturation) is more than $50 \%$, the ability of the bed to be a reservoir is determined by the ratio of bound and free water. With a residual water saturation close to the equilibrium saturation of both phases for a given rock (more than $75 \%$ for sandstones), the bed can be characterized by its properties as a fluid seal. The reservoir, in turn, can be potentially gas- or water-saturated, in the latter case, we can talk about areas of possible high water inflows. Gas deposit in the rock massif can be formed when the amount of bound water (residual water saturation) does not exceed $50 \%$ and the impact of external factors creates conditions for the water-gas separation.

The process of disturbing the natural equilibrium of the "water-gas" system with the subsequent formation of the tech- nogenic gas deposit in the coal massif can occur as follows: during the under-mining of sandstones, they are unloaded from the rock pressure, subside, broken by cracks. As a result of these processes, the permeability of sandstones increases sharply, large volumes of methane become mobile, they are directed to the mine workings and to the borehole bottom previously drilled from the mine workings or from the daylight surface. In this case, methane is released from technogenic accumulations that have formed in the process of sandstones underworking due to the increase in their permeability through the cracking. The formation of technogenic gas accumulations is associated with the formation of "concentrated" gas-water contact. In the area affected by technogenic cracks, which promote the connection between the pores in the sandstone, the gas tends to occupy a hypsometrically higher position, and water - a lower one. This process can be observed during the under-mining of degassing well drilled from the surface. Pure gas is first emitted from the well. This is the initial period of crack/fracture formation, when the free gas from the pores of sandstone, as more mobile and having a much lower viscosity than water, is directed by crack/fracture to the bottom of the well. Then for some time, a mixture of gas and water is taken out of the well. This corresponds to the period of intense cracking and the formation of a "concentrated" gas-water contact from the "scattered" one. Then it is time for the period of completion in the formation of the "concentrated" gaswater contact and the formation of technogenic accumulation of methane. It is characterized by intense methane gushing from the well.

In the given scheme in formation of technogenic gas accumulations, the determining factor is the process of decompaction and crack/fracture formation, which is associated with under-mining of rock massif by workings, i.e. the geomechanical factor that causes increased gas saturation (a degree of filling pores with gas) by increasing the volume of pore space, when the gas first acquires greater permeability and mobility and goes to the place of decompaction (less pressure).

Conventionally, the methane emission into the mine can be divided into two components: the methane flow associated with coal production and the methane release from the exposed surfaces of mine workings, not related to coal production. The first component reflects the methane flow into the mine workings from the loosened coal and from the rock massif, which is under the dynamic impact of the process in mining activity conducting and coal production. This component is determined by the specific methane content and changes in direct proportion to the volume of coal production. The second component demonstrates the drainage of methane from the surfaces of mine workings at the minimal dynamic impact of mining operations and in the absence of coal production works.

Paper [14] proposes a method for estimating the static methane potential for mines are being closed. The presence of correlation relationship between the values of annual coal production and the absolute methane content of the mine (annual methane emission), by multi-years measurements, allows us to use the obtained dependence to forecast the possible volumes of methane release according to the planned coal production data. Moreover, in the case of its extrapolation towards the reduction of coal production, up to the complete cessation, it is possible to determine the static methane content index, which generally characterizes the annual methane flow to the mine workings in case of coal production absence [16]. Fig. 1 schematically shows how the absolute methane content changes with an increase in the volume of produced coal (straight line $A B$ ). The relative methane content at point $B$ is defined as the ratio of $B F$ to $O F$ or as the ratio for the base of trapezoid $(O E B F) B F$ to its height $O F$. At point $A$, the relative methane content will correspond to the ratio of $O D$ to $A D$, and at point $E$, when coal production is zero, it will tend to an infinitude, like $O E / O \rightarrow \infty$. In the meantime, methane, al- 


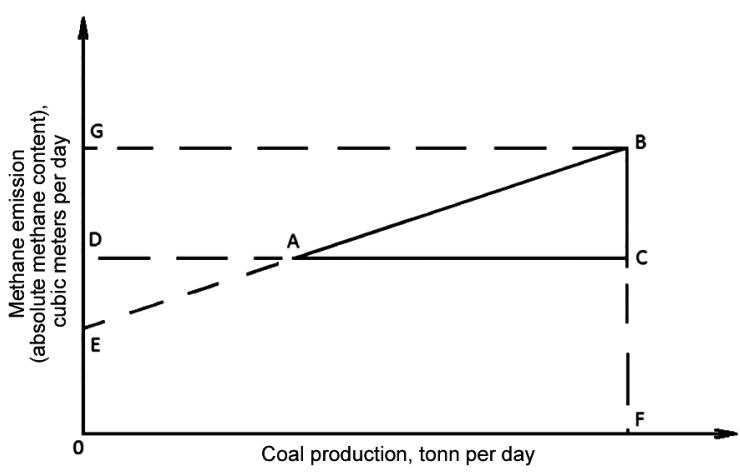

Fig. 1. Schematic (generalized) graph of dependence of absolute methane content of the extraction district on the volume of coal production [16]

though in small volumes, continues to be released into the mine workings even in the absence of coal production works, as is evidenced not only by the theoretical position of point $E$ schematically (Fig. 1), but also the graphs constructed in line with actual data [16].

It is this index (stable methane content), obtained with the help of the established dependence, and allows us to evaluate the static methane potential of the mine. Thus, the concept of static methane potential is defined as a generalized quantitative characteristic that allows forecasting the probable volumes of methane flow into the mine workings and evaluating the prospect of its excavation after mine closure.

However, in some cases, where there is a sharp increase in methane content, static methane potential may take a negative value, which prevents it from being used as an estimated figure. The same uncertainties can arise when using $Q_{s t}$ index - static methane content - proposed in paper [16] for analyzing methane emissions according to the methane content data concerning the methane content of the extraction district. More stable and always positive is $Q_{s}$ index - specific methane content - proposed in the same work, which characterizes the methane emission rate per unit time of coal production for 1 ton.

However, as it was shown in [16], the application of "relative methane content" index, which is normative, is impossible for forecasting because it has an inverse dependence on coal production, and in the case of extrapolation of its values towards the reduction of coal production, the value methane emissions are increasing. The value of any index of methane content does not allow separating methane emissions by sources of flow. Moreover, reliable forecasting of total methane emissions into mine workings based on the established dependencies between volumes of gas delivery and coal production significantly depends on the value of correlation coefficients between these indices. So, one of the purpose of this article is the search for the methodological approach to forecast the methane release with the definition of the main sources of its flow. The idea of the study involves using data on longterm monitoring of methane and coal production collected at mines, establishing stable values of specific methane emissions on their comparison, and forecasting methane emissions from various sources, which takes into account the natural methane-bearing capacity of coal, which has been determined at the geological exploration stage.

The absolute methane content data of the mine give evidence of the total ingress of gas into the mine, but do not divide methane volumes by gas-emission sources. The coal bed that is developed and the coalrock massif that contains it are the main sources of methane emission into the mine. Moreover, a part of methane emissions from the coalrock massif may be too significant. So the task that remains unresolved is to forecast methane emission from the coalrock massif separately from methane release from the coal beds that are developed.
The purpose is to develop an algorithm for forecasting the methane flow from the undermined coalrock massif consistent with coal production, the value of the absolute methane content and the methane content indexes of coal beds that are developed.

Methods. Statistical processing of actual data concerning the methane-bearing capacity of coal beds that are developed at the mines of the South-Donbas geological and industrial district of Donbas, as well as volumes of methane releases and coal production in these mines for ten years of their stable operation, presented in [17] are carried out. Methods of mathematical statistics, in particular correlation-regression analysis, were used to process experimental data. To forecast the total volume of methane flow into the workings of existing or closed mines, it is necessary to use stable values of specific methane emissions, i.e. volumes of methane flow per ton of extracted coal. To take this into account, the values of specific annual methane emissions were analyzed by comparing the ratio of successively accumulated over the years volumes of coal production in mines and volumes of methane emissions in "Pivdenno-Donbaska-1" and "Pivdenno-Donbaska-3" mines.

Information about the ash content and coal humidity at "Pivdenno-Donbaska-1" and "Pivdenno-Donbaska-3" mines were also used. It was obtained at the stage of geological exploration, which allowed determining the natural and residual methane-bearing capacity of coal, and consequently, calculating more accurately the volumes of methane flows from the coal beds that are developed, in particular the value of specific methane emission from the coal beds. On the basis of the obtained stable values of specific methane emissions and forecasting volumes of coal production, the total volumes of methane flow are calculated, and with the exception of methane emissions from coal beds, methane flow only from the coal massif is tentatively determined.

Results. Coal mine methane emissions in coalrock massifs are controlled by natural and technogenic factors which cause crack formation, improve the filtration-capacitive properties of rocks and make the gas more mobile, which allows it to concentrate in certain zones. During the period of mining operations at the mine, the coalrock massif is intensively undermined, unloaded from rock pressure, cracked and becomes favorable for the drainage of methane gas from it into the mine workings. The larger the contact area of the mined-out space with the undermined massif is, the larger portions of gas can go into the mine. Thus, the sources of methane flow into the mine involve the developed coal bed (both destroyed coal and its free surfaces on the walls of mine workings), underworked and overworked coalrock massif (beds-satellites and host rocks in the roof and bottom of the working bed), produced space of the abandoned longwalls. The volumes of methane emission into mine workings depend on the gas-bearing capacity of coal-bearing sediments, the degree of their permeability and the size of the rock massif affected by the mine workings, both in area and depth. The nature of this process is influenced by the volume of mined-out space in the abandoned longwalls, the area of free surfaces of coal beds on the walls of mine workings, volumes of underworked and overworked coalrock massifs that are favorable for the storage of technogenic gas accumulations [16]. In general, it is methane from the developed coal bed and from the coalrock massif.

"Pivdenno-Donbaska-1" and "Pivdenno-Donbaska-3" mines are objects of the research that are located within the boundaries of South-Donbas district. Southern Donbas or South-Donbas geological-industrial district is known as the strip of distribution of Lower Carboniferous sediments on the south-western outskirts of the Donetsk basin. In the north, the district borders with Pokrovskyi (former Chervonoarmiiskyi), in the northeast - with Donetsko-Makiivskyi geological-industrial districts, the southern and south-eastern border of the district runs along the line of wedging of sediments with industrial coal content. The area of the district is approximately $560 \mathrm{~km}^{2}$. 
The geological structure of the district includes deposits of the Precambrian basement, Upper Devonian, Lower Carboniferous, Lower Jurassic, Upper Cretaceous, Paleogene, Neogene, and Quaternary ages. Rock outcrops of the Precambrian foundation edge the district from the south and are represented by metamorphosed and effusive differences of the Ukrainian Crystalline Shield (UCS). There is a sedimentary-effusive stratum of the Upper Devonian age on the crystalline basis, its thickness in the east of the district reaches 600 and more meters.

Lower Carboniferous sediments are represented by a full section: Tournaisian, Visean and Serpukhovian (stages) suites $C_{1}^{1}-C_{1}^{5}$ and are conventionally divided into two strata: lower - carbonate (suite $C_{1}^{1}$ ) and upper - terrigenous. The thickness of the carbonate stratum is from 90 to $500 \mathrm{~m}$, and the terrigenous stratum is from 1450 to $2750 \mathrm{~m}$. Suites $C_{1}^{3}$ and $C_{1}^{4}$, which contain up to 119 coal beds and layers, are coalbearing ones, thirty-five of which have a working thickness. Six beds are stable and relatively stable: $c_{4}^{2}, c_{5}^{1}, c_{6}^{1}, c_{9}^{2}, c_{10}^{2}$, $c_{13}$. Other beds are very unstable. Beds of simple structure predominate. Complex $2-3^{\text {th }}$ pack structure is typical of beds of suites $C_{1}^{4}$ and $C_{1}^{5}$. The predominant mass of coal in the district by the degree of metamorphism belongs to gas ones, coal of higher stages of metamorphism is less developed. Carboniferous sediments overlap with the disagreement of Jurassic clays and sandstones, which are found in the form of lenses up to $22 \mathrm{~m}$ thick.

Upper Cretaceous sediments lie inconsistently on all older sediments. They are composed of spongolites, marls, chalk, aleurolites of up to $145 \mathrm{~m}$ thickness. Above the Cenozoic formations lie discordantly, they are represented by Paleogene, Neogene and Quaternary sands, sandstones, clays and loams of up to $130 \mathrm{~m}$ thickness.

Structurally, the district is located within a flat monocline, which passes into the southern wing of the Kalmius-Toretska kettle hole and is confined to the area connecting the Donetsk basin with the northern slope of the UCS. Characteristic of the area is the flat angles of rock fall $\left(5-12^{\circ}\right)$, which sometimes acquire a steeper fall associated with plicative structures and disjunctive faults. Thus, in the central part of the district is the submeridional Vovchanska syncline. Among the minor folds, there is a long chain of brachianticlines extending in the northwestern direction along with the regional Kryvorizko-Pavlivskyi faulting, and a number of folds in the north-eastern direction in the eastern wing of the Vovchanska syncline. Longitudinal and diagonal faultings, mostly of the north-western extension, received the predominant development of disjunctive disorders. The largest fault of the north-eastern fall is Kryvorizko-Pavlivskyi, which has an amplitude of 250 to $1100 \mathrm{~m}$. Hirnychyi and Maksymovskyi faults are smaller with an amplitude of 150 to $300 \mathrm{~m}$ also have a north-eastern fall. There are faults of the south-western fall, such as Volodymyrivskyi, Shevchenkivskyi, Dolynnyi and others with amplitudes of up to $100-150 \mathrm{~m}$. In the north-eastern part of the district, there are Yalynskyi and Tsentralnyi thrusts, which are on the border with Donetsk-Makiivskyi district.

The coal-bearing stratum has a high gas capacity, which increases with depth. Productive carboniferous sediments of the Southern Donbas lie almost entirely in the zone of methane gases, the surface of which is located mainly at a depth of $170-200 \mathrm{~m}$ and approximately coincides with the bottom of the cover Mesocainozoic sediments. Only in the south-east of the district, the depth of the degassing zone increases to marks of $300-440 \mathrm{~m}$. A distinctive feature of hydrocarbon gases is the presence of high concentrations of helium, sometimes hydrogen, in the gas mixture.

The gas capacity of productive sediments varies from 6 to $22 \mathrm{~m}^{3} / \mathrm{t}$ of dry ashless mass $\left(\mathrm{m}^{3} / \mathrm{t}\right.$ d.a.m. $)$, on average it is $15 \mathrm{~m}^{3} / \mathrm{t}$ d.a.m. The operating mines of the Southern Donbas are super-categorical in terms of the gas regime from a depth of $300-400 \mathrm{~m}$. The relative methane content of stopes can reach 30-40 $\mathrm{m}^{3} / \mathrm{t}$ (mine "Pivdenno-Donbaska-3").

The methane-bearing capacity of coal beds is generally evenly distributed over the area. Relatively high values of methane-bearing capacity are observed in zones of complex tectonic structure: near thrusts, vaulted and flexural uplifts, where the presence of small gas accumulations of the classical type is possible. Thus, near Kryvorizko-Pavlovskyi, Maksymivskyi and other faults and thrusts, the methane-bearing capacity of coal beds $c_{10}^{1}, c_{6}^{1}$ and $c_{4}^{0}$ is significantly increased and reaches from 21.8 to $25.0 \mathrm{~m}^{3} / \mathrm{t}$ d.a.m.

In agreement with the results of KII-65 research for enclosing rocks of the southern part of the area, it was found that most of the sandstones contain gas in the water-soluble state and have a gas capacity of 0.15 to $0.36 \mathrm{~m}^{3} / \mathrm{m}^{3}$. But it is reported that individual sandstone horizons $\left(\mathrm{c}_{4} \mathrm{Sc}_{5}, \mathrm{c}_{6} \mathrm{OSc}_{8}\right.$, etc. $)$ may contain methane in a free state.

Within the South Donbas district, in the southern zone of small folding, there are two mines "Pivdenno-Donbaska-1" and "Pivdenno-Donbaska-3". These mines analyzed data on methane flow during $\mathrm{c} 11$ bed production for 10 years.

"Pivdenno-Donbaska-1" mine. The bed thickness is $1.3 \mathrm{~m}$ with a natural gas capacity of $9-11 \mathrm{~m}^{3} / \mathrm{t}$. Based on the values of coal production and methane flow (Table 1), a graph of the relationship between these indices was constructed (Fig. 2).

The linear correlation coefficient between the volumes of methane flow into the mine workings and the volumes of extracted coal is 0.76 with a reliability of 5.8 .

"Pivdenno-Donbaska-3" mine. The bed thickness is $1.65 \mathrm{~m}$ with a natural gas capacity of $10-16 \mathrm{~m}^{3} / \mathrm{t}$. According to

Table 1

Coal production and methane emission at "PivdennoDonbaska-1" mine

\begin{tabular}{|c|c|c|c|c|}
\hline $\begin{array}{c}\text { Years } \\
\text { of } \\
\text { mining }\end{array}$ & $\begin{array}{c}\text { Volumes of } \\
\text { coal mining, } \\
\text { thousand, } \\
\text { t/year }\end{array}$ & $\begin{array}{c}\text { Methane } \\
\text { emission, } \\
\text { million, } \\
\mathrm{m}^{3} / \text { year }\end{array}$ & $\begin{array}{c}\text { Cumulative } \\
\text { production, } \\
\text { thousand, } \mathrm{t}\end{array}$ & $\begin{array}{c}\text { Cumulative } \\
\text { emission, } \\
\text { million, } \mathrm{m}^{3}\end{array}$ \\
\hline 1 & 1752.00 & 32.40 & 1752.00 & 32.40 \\
\hline 2 & 1679.00 & 32.80 & 3431.00 & 65.20 \\
\hline 3 & 1058.50 & 23.97 & 4489.50 & 89.17 \\
\hline 4 & 1062.15 & 15.88 & 5551.65 & 105.05 \\
\hline 5 & 1219.10 & 17.87 & 6770.75 & 122.92 \\
\hline 6 & 1120.55 & 18.82 & 7891.30 & 141.74 \\
\hline 7 & 846.80 & 17.19 & 8738.10 & 158.93 \\
\hline 8 & 1299.40 & 12.35 & 10037.50 & 171.28 \\
\hline 9 & 1261.90 & 21.86 & 11299.40 & 193.14 \\
\hline 10 & 1133.40 & 17.27 & 12432.80 & 210.41 \\
\hline
\end{tabular}

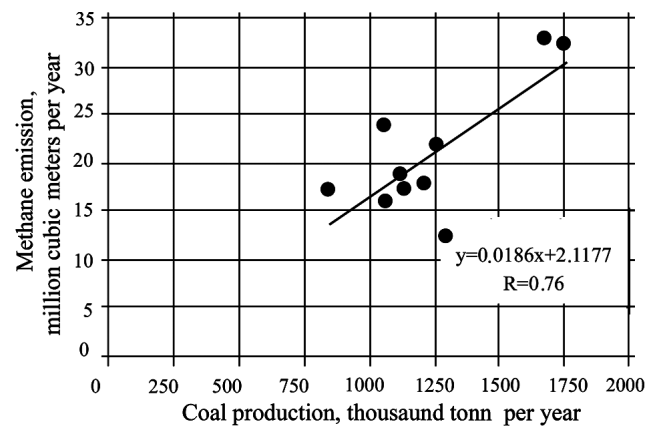

Fig. 2. Dependence of methane emissions on coal production at "Pivdenno-Donbaska-1" 
the values of coal production and methane emissions (Table 2), a corresponding graph was also constructed (Fig. 3).

The linear correlation coefficient between methane emissions into mine workings and volumes of extracted coal is 0.64 with a reliability of 3.5 .

According to the analysis, the annual gas emission in mines is very variable, so for a generalized estimation of stable methane flow into mine workings, the annual volumes of produced coal and annual volumes of released methane for ten years are analyzed in the sequence of their accumulation (Figs. 4, 5). With such an approach, the correlation coefficients between the accumulated methane emissions into the mine workings and the volumes of produced coal are 0.99 and they are more reliable. The volumes of methane release characterize the angle of slope of a regression line for the obtained dependences.

The nature of the refinement of the average value of the relative methane content can be illustrated more clearly by graphs (Figs. 6, 7) constructed by years, in the sequence of accumulation of initial data for ten years. For a generalized estimation of the steady-state value of specific methane emissions, the data were averaged sequentially each year, i.e. points by which the graphs are constructed is a partial from the division of accumulated methane emission by the corresponding accumulated coal production.

Figs. 6 and 7 show that the curves characterizing the changes in the values of specific methane emissions averaged over the years of observation are gradually stabilizing, which gives evidence of the obtaining of a sufficiently stable value of this index when summarizing data for ten years of observations. Thus, for the mine "Pivdenno-Donbaska-1" the specific methane emission generalized for ten years is $16.9 \mathrm{~m}^{3} / \mathrm{t}$, the relative error for the last 3 years is $1.2 \%$. The specific

Table 2

Coal production and methane emission at "PivdennoDonbaska-3" mine

\begin{tabular}{|c|c|c|c|c|}
\hline $\begin{array}{c}\text { Years } \\
\text { of } \\
\text { mining }\end{array}$ & $\begin{array}{c}\text { Volumes of } \\
\text { coal mining, } \\
\text { thousand } \\
\text { t/year }\end{array}$ & $\begin{array}{c}\text { Methane } \\
\text { emission, } \\
\text { million, } \\
\mathrm{m}^{3} / \text { year }\end{array}$ & $\begin{array}{c}\text { Cumulative } \\
\text { production, } \\
\text { thousand, } \mathrm{t}\end{array}$ & $\begin{array}{c}\text { Cumulative } \\
\text { emission, } \\
\text { million, } \mathrm{m}^{3}\end{array}$ \\
\hline 1 & 985.50 & 13.10 & 985.50 & 13.10 \\
\hline 2 & 985.50 & 16.30 & 1971.00 & 29.40 \\
\hline 3 & 584.00 & 12.09 & 2555.00 & 41.49 \\
\hline 4 & 886.95 & 15.77 & 3441.95 & 57.26 \\
\hline 5 & 532.90 & 11.72 & 3974.85 & 68.98 \\
\hline 6 & 620.50 & 16.29 & 4595.35 & 85.27 \\
\hline 7 & 686.20 & 11.72 & 5281.55 & 96.99 \\
\hline 8 & 1069.45 & 18.14 & 6351.00 & 115.13 \\
\hline 9 & 1036.00 & 24.70 & 7387.00 & 139.83 \\
\hline 10 & 1224.90 & 18.16 & 8611.90 & 157.99 \\
\hline
\end{tabular}

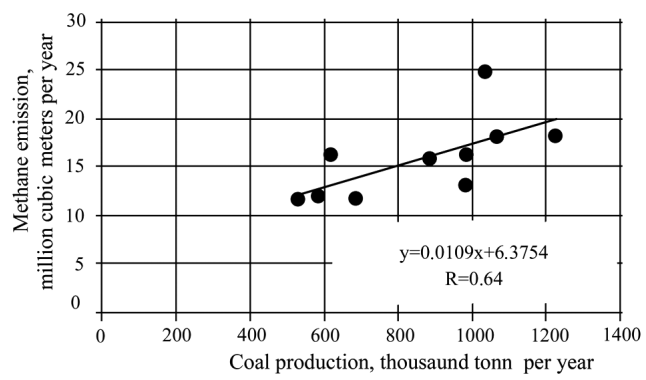

Fig. 3. Dependence of methane emission on coal production at "Pivdenno-Donbaska-3"

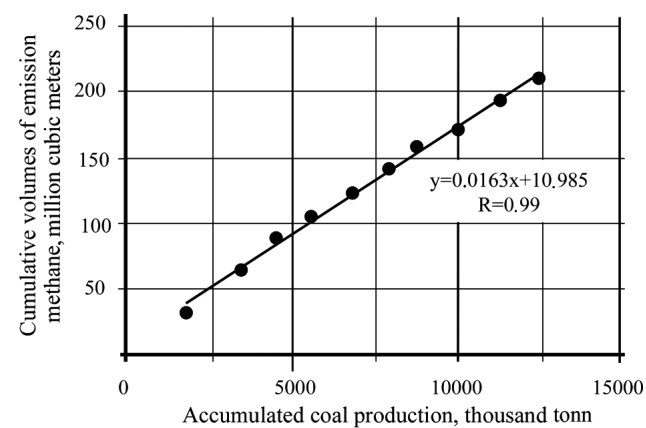

Fig. 4. Dependence of the accumulated volumes of released methane on the accumulated coal production at "PivdennoDonbaska-1"

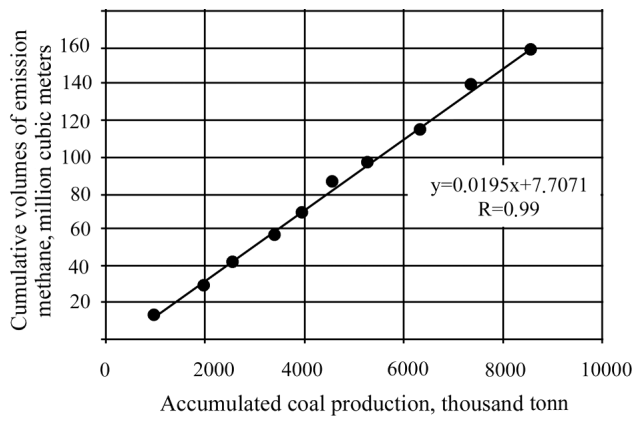

Fig. 5. Dependence of the accumulated volumes of released methane on the accumulated coal production at "PivdennoDonbaska-3"

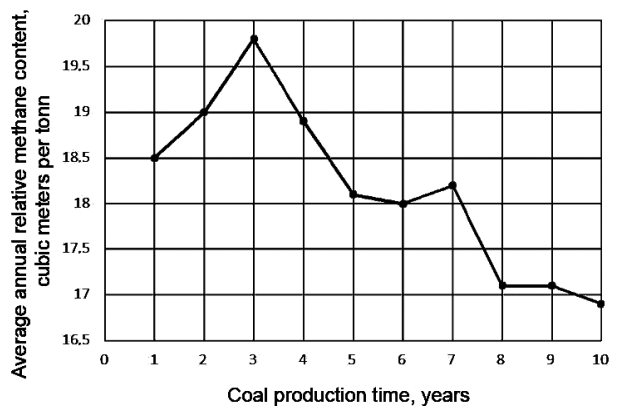

Fig. 6. Change in the averaged values of specific methane emissions by years at "Pivdenno-Donbaska-1"

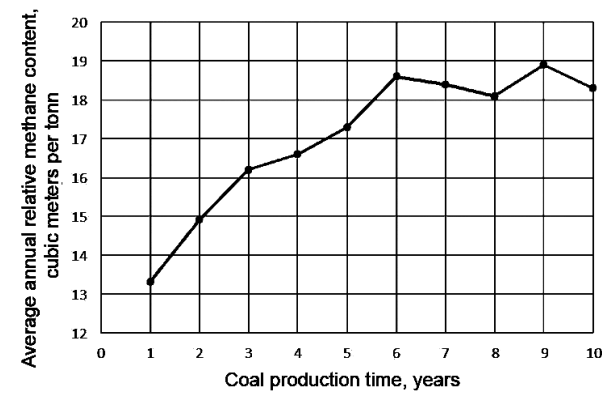

Fig. 7. Change in the averaged values of specific methane emissions by years at "Pivdenno-Donbaska-3"

methane emission for the mine "Pivdenno-Donbaska-3", determined according to a similar approach, is $18.3 \mathrm{~m}^{3} / \mathrm{t}$, the relative error for the last 3 years is $3.3 \%$.

The actual arithmetic mean value of annual production at the mine "Pivdenno-Donbaska-1" for ten years is 1243.28 thousand tons. According to the specific emission of 
methane $16.9 \mathrm{~m}^{3} / \mathrm{t}$, generalized for ten years, with an average annual production of 1243.28 thousand tons, an average of 21.0 million $\mathrm{m}^{3}$ of methane is released into the mine every year. It is a gas from the developed coal bed and from the rock massif.

The arithmetic mean value of annual production at the mine "Pivdenno-Donbaska-3" for ten years is 861.2 thousand tons. According to the specific emission of methane $18.3 \mathrm{~m}^{3} / \mathrm{t}$, generalized for ten years, with an average annual production of 861.2 thousand tons, 15.8 million $\mathrm{m}^{3}$ of gas is released into the mine.

With regard to the data presented in [18], such as the volatile-matter content in coal beds, ash content, humidity, and residual methane-bearing capacity, we can calculate methane emissions from the coal bed, which will be equal to its natural gas capacity minus residual methane-bearing capacity.

For the mine "Pivdenno-Donbasska-1" the volatile-matter content in coal beds varies between $41.0-42.9 \%$, ash content averages $6.1 \%$, humidity $6.2 \%$ [18], and residual methane-bearing capacity, according to [19], is $1.68 \mathrm{~m}^{3} / \mathrm{t}$. Methane emissions from the coal bed at the average natural gas capacity will be equal to $10-1.68=8.32 \mathrm{~m}^{3} / \mathrm{t}$.

Given that the average annual production at the mine is 1243.28 thousand tons, the release of methane from the coal bed during this time will be 10.3 million $\mathrm{m}^{3}$, and from the coalrock massif of $21.0-10.3=10.7$ million $\mathrm{m}^{3} /$ year.

For the mine "Pivdenno-Donbasska-3" the volatile-matter content of coal beds varies between $35.2-42.6 \%$, ash content averages $6.6 \%$, humidity $6.0 \%$ [18], so the residual methane-bearing capacity, according to the table data on the determination of residual methane-bearing capacity by the rate of volatile-matter content of coal beds, is $1.79 \mathrm{~m}^{3} / \mathrm{t}$. Thus, methane emissions from the coal bed with an average natural gas capacity will be $13-1.79=11.21 \mathrm{~m}^{3} / \mathrm{t}$

Given that the average annual production at the mine is 861.2 thousand tons, the release of methane from the produced coal during this time will be 9.7 million $\mathrm{m}^{3}$, and from the coalrock massif, respectively, $15.8-9.7=6.1$ million $\mathrm{m}^{3} /$ year.

The obtained values of the specific methane emission of the mines of the South-Donbas geological-industrial district allow us to calculate the forecast values of the ingress of gas from the rock mass, taking into account the volumes of methane emission and coal production that have occurred in recent years. Thus, given the annual total methane emissions in the amount of about 16 million $\mathrm{m}^{3}$ per year in the mine "Pivnichno-Donbaska 3", and the loss during this time (20 years) more than 300 million $\mathrm{m}^{3}$ of gas, which is $8.5 \%$ from the total reserves, the term of the possible production of hydrocarbon raw materials from the hydrocarbon massif of the mine can be more than 100 years.

Knowing the annual averaged volumes of coal production and methane flow from the rock massif, it is possible to calculate the value of specific methane emissions separately from the rock massif. For "Pivdenno-Donbaska-1" mine, it will be $8.6 \mathrm{~m}^{3} / \mathrm{t}$, or $51 \%$ of the total methane supply to the mine. For "Pivdenno-Donbaska-3" mine, the specific emission from the rock mass is $7.1 \mathrm{~m}^{3} / \mathrm{t}$, which is almost $39 \%$ of the total methane emissions at the mine.

Conclusions. Analysis of mining and geological conditions in the development of "Pivdenno-Donbasska-1" and "Pivdenno-Donbasska-3" mines, located in the territory controlled by Ukraine, showed that the production potential of these mines is favorable for the organization of work on industrial production and utilization of mine methane.

Thus, for "Pivdenno-Donbasska-1" and "PivdennoDonbasska-3" mines the algorithm of forecasting estimation of methane emission from undermined coalrock massif, which consists in establishing generalized values of specific methane emissions, determining the specific methane emissions from coal. For this, we take into account natural and residual methane-bearing capacity of coal beds, which are developed, and approximately estimate volumes of methane emissions from the rock mass surrounding the working coal beds.

Thus, the above algorithm allows quantifying the flow of gas from the undermined coalrock massif according to the annual coal production, the values of the absolute methane content of the mine, the values of natural and residual methanebearing capacity of coal. For "Pivdenno-Donbaska-1" mine, the projected annual volume of methane release from the coal massif is 10.7 million $\mathrm{m}^{3}$ per year; for "Pivdenno-Donbaska-3" mine it is approximately 6.1 million $\mathrm{m}^{3}$ per year.

The projected volumes of methane flow can be corrected with the consideration of the current data on coal production, or its absence and the established values of specific methane emissions, which will allow ensuring safe mining conditions at operating mines and evaluating the prospects of its industrial production from the undermined space of the abandoned mine after mining.

\section{References.}

1. Rudko, H. I. (2017). Energy resources of the geological environment of Ukraine and their importance for national security of the state. Proceedings of the International Geological Forum "Actual Problems and Prospects of Development of Geology: Science and Production" (Geoforum-2017), 284-286.

2. Maydukov, G. L. (2015). Resource potential of mine methane in the energy sector of Ukraine. Ugol Ukrainy, 10, 38-45. 3. Sheyko, A. V. (2017). The method for determining methane reserves in the coal-rock massif of the Donetsk basin. GeoTechnical mechanics, 137, 180-190.

4. Prykhodchenko, V. F., Khomenko, N. V., Zhykalyak, M. V., Prykhodchenko, D. V., \& Tokar, L. O. (2019). Influence of local orogeny and reservoir characteristics of enclosing rocks on the location of gas traps within the coal bearing deposits. Naukovyi Visnyk Natsionalnoho Hirnychoho Universytetu, (5), 1115. https://doi.org/10.29202/nvngu/2019-5/1.

5. Moisyshyn, V. M., Naumko, I. M., Pylypets, V.I., Radchenko, V. V., Khalimendikov, S. M., Kozhushok, O. D., ..., \& Turchyn, V.A. (2013). Complex development of gas-coal deposits on the basis of string technologies in the well-drilling. Kyiv: Naukova Dumka.

6. Tong, R., Yang, Y., Ma, X., Zhang, Y., Li, S., \& Yang, H. (2019). Risk Assessment of Miners' Unsafe Behaviors: A Case Study of Gas Explosion Accidents in Coal Mine, China. International Journal of Environmental Research and Public Health, 16(10), 1765. https://doi.org/10.3390/ijerph16101765.

7. Brodny, J., \& Tutak, M. (2016). Analysis of Methane Emission into the Atmosphere as a Result of Mining Activity, 16th ed.; International Multidisciplinary Scientific GeoConference SGEM: Sofia, Bulgaria, 4(3), 83-90.

8. Mineev, S. P., Kocherga, V. M., Korneev, Yu.A., Yanzhula, O.S., Gulay, O.O., \& Samopalenko, P. M. (2018). Research of the methan content effecting on gas-draine efficiency in the stope when boreholes are left in uncontrollable workings, Geo-Technical mechanics, 141, 107-123. https://doi. org/10.15407/geotm2018.141.107.

9. Mineev, S.P., Kocherga, V. N., Narivskiy, R. N., \& Yanzhula, A. S. (2018). Questions of the analysis of the applicable schemes of conveying the moving sites on Ukrainian mines and effectiveness of degasation. Modern Scientific Researches, 3(1), 35-43.

10. Bezruchko, K., Prykhodchenko, O., \& Tokar, L. (2014). Prognozis for free methane traps of structural and tectonic type in Donbas. Progressive Technologies of Coal, Coalbad Methane, and Ores Mining, 267-271. https://doi.org/10.1201/ b17547-47.

11. Tutak, M., \& Brodny, J. (2019). Forecasting Methane Emissions from Hard Coal Mines Including the Methane Drainage Process. Energies, 12(20), 38-40. https://doi. org/10.3390/en 12203840.

12. Crow, D. J. G., Balcombe, P., Brandon, N., \& Hawkes, A. D. (2019). Assessing the impact of future greenhouse gas emissions 
from natural gas production. Science of The Total Environment, 668, 1242-1258. https://doi.org/10.1016/j.scitotenv.2019.03.048. 13. Prykhodchenko, V.F., Sdvyzhkova, O.O., Khomenko, N. V., \& Tykhonenko, V. V. (2016). Effect of time-transgressive faults upon methane distribution within coal seams. Naukovyi Visnyk Natsionalnoho Hirnychoho Universytetu, (1), 31-35.

14. Lukinov, V. V., \& Chernorai, A. M. (2017). Forecasting the static methane potential of coal mines. Ugol Ukrainy, 5-6(725726), 21-25.

15. Bulat, A.F., Lukinov, V.V., \& Bezruchko, K.A. (2017). Conditions of gas traps forming in carboniferous sediments. Kyiv: Naukova dumka.

16. Lukinov, V. V., Bezruchko, K. A., \& Prykhodchenko, O. V. (2015). Methane distribution estimation in coal-rock massif according to the methane content of mining extracted sections. Ugol Ukrainy, 11, 16-19.

17. Triplet, D. R., Filippov, A. E., \& Pisarenko, A. A. (2000). Methane of coal deposits of Ukraine: production and investment potential of the mines of Donbass. Kyiv: Logos.

18. Antsiferov, A.V., Golubev, A.A., Kanin, V.A., Tirkel, M. G., Zadara, G. Z., Uziyuk, V. I., ..., \& Suyarko, V. G. (2009). Gas content and methane resources of coal basins in Ukraine. Donetsk: Veber.

19. NPAOP 10.0-7.08-93 (1993). Guidelines for designing ventilation of coal mines. 3. Retrieved from http://pdf.sop.zp.ua/ npaop_10_0-7_08-93.pdf.

\section{Прогноз емісії метану з підробленого вуглепородного масиву}

\section{В. В. Лукінов ${ }^{1}$, К. А. Безручко ${ }^{2}$, М. В. Жикаляк ${ }^{3}$, О. В. Приходиенко ${ }^{2}$, Г. О. Бердик 1}

1 - Національний технічний університет «Дніпровська політехніка», м. Дніпро, Україна, e-mail:gvrvg@meta.ua 2 - Інститут геотехнічної механіки імені М. С. Полякова НАН України, м. Дніпро, Україна

3 - ДРГП „Донецькгеологія”, м. Бахмут, Україна

Мета. Розробити алгоритм прогнозної оцінки емісії метану з підробленого вуглепородного масиву за даними видобутку вугілля, значенням абсолютної метановості шахти та показникам метаноносності вугільних пластів, що розробляються.

Методика. Статистична обробка фактичних даних щодо метаноносності вугільних пластів, що розробляються, а також обсягів метановиділення й видобутку вугілля. На підставі отриманих сталих значень питомої емісії метану та обсягів видобутку вугілля розраховуються загальні обсяги надходження метану, а за винятком метановиділення з вугільних пластів, оцінюються обсяги надходження метану з вуглепородного масиву.

Результати. Розроблено алгоритм прогнозу кількісної оцінки емісії метану з підробленого вуглепородного масиву діючих вугільних шахт. Проведено аналіз даних щодо емісії метану під час відроблення вугільних пластів на шахтах «Південно-Донбаська-1» та «Південно-Донбаська-3» Південно-Донбаського геолого-промислового району Донбассу за 10 років. Розроблено алгоритм прогнозної оцінки емісії метану з підробленого вуглепородного масиву, що полягає у встановлені узагальнених значень питомої емісії метану в шахту, розрахунку питомої емісії метану з вугілля, на підставі врахування природної й залишкової метаноносності вугільних пластів, що розробляються та орієнтовної оцінці об'ємів метановиділення з гірського масиву, що вміщує робочі вугільні пласти.

Наукова новизна. Уперше розроблено алгоритм кількісної оцінки емісії метану окремо з підробленого вугле- породного масиву вугільних шахт і наведені приклади його практичного застосування шляхом розрахунку за гірничо-геологічними даними на шахтах «ПівденноДонбаська-1» та «Південно-Донбаська-3».

Практична значимість. Розроблений алгоритм розрахунку емісії метану з підробленого вуглепородного масиву може бути використаний для прогнозу емісії метану діючих і закритих шахт з метою оцінки можливості його практичного промислового видобутку.

Ключові слова: вугільні шахти, підроблений вуглепородний масив, емісія метану, прогноз емісії

\section{Прогноз эмиссии метана из подработанного углепородного массива}

\section{В. В. Лукинов ${ }^{1}$, К. А. Безручко ${ }^{2}$, Н. В. Жикаляк ${ }^{3}$, А. В. Приходченко ${ }^{2}$, Г.А. Бердик ${ }^{1}$}

1 - Национальный технический университет «Днепровская политехника», г. Днепр, Украина, e-mail: gvrvg@ meta.ua

2 - Институт геотехнической механики имени М. С. Полякова НАН Украины, г. Днепр, Украина

3 - ГРГП „Донецкгеология”, г. Бахмут, Украина

Цель. Разработать алгоритм прогнозной оценки эмиссии метана из подработанного углепородного массива по данным добычи угля, значениям абсолютной метанообильности шахты и показателям метаноносности разрабатываемых угольных пластов.

Методика. Статистическая обработка фактических данных по метаноносности разрабатываемых угольных пластов, а также объемов метановыделения и добычи угля. На основании полученных значений эмиссии метана и объемов добычи угля рассчитываются общие объемы поступления метана, за исключением метановыделения из угольных пластов, оцениваются объемы поступления метана из углепородного массива.

Результаты. Разработан алгоритм прогноза количественной оценки эмиссии метана из подработанного углепородного массива действующих угольных шахт. Проведен анализ данных по эмиссии метана при отработке угольных пластов на шахтах «Южно-Донбасская-1» и «Южно-Донбасская-3» Южно-Донбасского геолого-промышленного района Донбасса за 10 лет. Разработан алгоритм прогнозной оценки эмиссии метана из подработанного углепородного массива, который заключается в установлении обобщенных значений эмиссии метана в шахту, расчета удельной эмиссии метана из угля на основании учета природной и остаточной метаноносности разрабатываемых угольных пластов и ориентировочной оценки объемов метановыделения из вмещающего рабочие угольные пласты горного массива.

Научная новизна. Впервые разработан алгоритм количественной оценки эмиссии метана отдельно из подработанного углепородного массива угольных шахт и приведены примеры его практического применения путем расчета по горно-геологическим данным на шахтах «Южно-Донбасская-1» и «Южно-Донбасская-3».

Практическая значимость. Разработанный алгоритм расчета эмиссии метана из подработанного углепородного массива может быть использован для прогноза эмиссии метана действующих и закрытых шахт с целью оценки возможности его практической промышленной добычи.

Ключевые слова: угольные шахты, подработанный углепородный массив, эмиссия метана, прогноз эмиссии

Recommended for publication by L. I. Pymonenko, Doctor of Geological Sciences. The manuscript was submitted 15.12.19. 